\title{
Comparison of Qiagen and lontek Hepatitis B Virus-DNA Polymerase Chain Reaction Quantitation Kits in Chronic Hepatitis B Patients Infected with Hepatitis B Virus Genotype D
}

\author{
Hepatit B Virüs Genotip D ile Enfekte Kronik Hepatit B'li Hastalarda Qiagen ve lontek \\ Hepatit B Virüs-DNA Polimeraz Zincir Reaksiyonu Kantitasyon Kitlerinin Karșılaștırılması
}

\author{
๑ Ayse Arikan 1,3, @ Murat Sayan2,3 \\ ${ }^{1}$ Near East University Faculty of Medicine, Department of Medical Microbiology and Clinical Microbiology, Nicosia, Northern Cyprus \\ 2Kocaeli University Faculty of Medicine, Clinical Laboratory, PCR Unit, Kocaeli, Turkey \\ ${ }^{3}$ Near East University, DESAM Institute, Nicosia, Northern Cyprus
}

\begin{abstract}
Objectives: Hepatitis B virus (HBV)-DNA level is a good marker for viral replication and should be monitored at regular intervals in patients with chronic hepatitis B (CHB). The objective of this study is to compare the performance of Qiagen HBV-DNA kit with lontek HBV-DNA kit and to determine the usability of lontek.

Materials and Methods: Serum samples of 87 patients who had been identified as HBV genotype D previously, were sent to Kocaeli University for HBV-DNA quantitation. Serum HBV-DNA levels were determined by real-time polymerase chain reaction method using both systems simultaneously. The calculated viral load values were converted to logarithmic values and used for statistical comparison of two kits. T-test was used to study the statistical difference between two methods. The statistical comparison and the linearity between the two results were determined by Bland-Altman plot and Passing-Bablok analyses respectively.

Results: Log HBV-DNA results in Qiagen and lontek kits were within the $95 \%$ confidence interval of the bias $(-0.84$; standard deviation: 0.67). There was no significant difference and the relationship between two variables was linear.

Conclusion: The comparative distribution analysis of Qiagen and lontek kits indicated that a product produced in our country can be safely used in the treatment follow-up of patients with $\mathrm{CHB}$. These type of studies may support the production of high value-added products in our country and also they can be utilized by other users in the world.

Keywords: Hepatitis B, real-time polymerase chain reaction, HBVDNA
\end{abstract}

ÖZ

Amaç: Hepatit B virüs (HBV)-DNA düzeyi viral replikasyonun iyi bir göstergesidir ve kronik hepatit B'li (KHB) hastalarda düzenli aralıklarla izlenmelidir. Bu çalışmada amaç, Qiagen HBV-DNA viral yük kiti ve lontek HBV-DNA viral yük kitinin performans karşılaştırmasını yapmak ve lontek kitinin kullanılabilirliğini belirlemektir.

Gereç ve Yöntemler: Çalışmaya Kocaeli Üniversitesi'ne HBV-DNA kantitasyonları yapılmak üzere gönderilen ve önceden HBV genotip D olduğu tanımlanmış 87 hastanın serum örnekleri dahil edilmiştir. Serum HBV-DNA düzeyleri, her iki sistem de eş zamanlı kullanılarak, gerçek zamanlı polimeraz zincir reaksiyonu yöntemiyle belirlenmiştir. Elde edilen viral yük değerleri, logaritmik değer dağlımlarına çevrilmiş ve her iki kitin karşılaştııımasında kullanılmıştır. Iki metot arasındaki istatistiksel fark, t-testi kullanılarak araştırımıştır. Her iki ölçüm arasındaki istatistiksel karşılaştırma Bland-Altman dağlım analizi ile belirlenirken, sonuçlar arasındaki doğrusallık Passing-Bablok dağılım analizi kullanılarak saptanmıştır.

Bulgular: Elde edilen sonuçlara göre Qiagen ve lontek kitlerinde, log HBV-DNA sonuçlarının \%95 güven aralığı içinde yanlılık $(-0,84$, standart sapma: 0,67 ) uyumlu olduğu, anlamlı bir fark olmadığı ve iki değişken arasındaki ilişkinin doğrusal olduğu tespit edilmiştir.

Sonuç: Qiagen ve lontek HBV-DNA viral yük kitlerinin karşılaştırmalı dağılım analizleri bize ülkemizde üretilmiş bir ürünün, KHB'li hastaların tedavi takibinde güvenle kullanılabileceğini göstermektedir. Bu gibi çalışmalar, ülkemizde katma değeri yüksek ürünlerin üretilmesini desteklerken, bu tür ürünlerin dünyadaki diğer kullanıcılara da ulaştırıımasına imkan tanıyabilir.

Anahtar Kelimeler: Hepatit B, gerçek zamanlı polimeraz zincir reaksiyonu, HBV-DNA

Arikan A, Sayan M. Comparison of Qiagen and lontek Hepatitis B Virus-DNA Polymerase Chain Reaction Quantitation Kits in Chronic Hepatitis B Patients Infected with Hepatitis B Virus Genotype D. Viral Hepat J. 2020;26:9-13. 


\section{Introduction}

The hepatitis B virus (HBV) affects more than 257 million people worldwide and is a potential life threat resulting in 880.000 deaths per year (1). The prevalence of HBV infection varies according to geographical regions around the world, but the highest seroprevalence of hepatitis B surface antigen ( $\mathrm{HBsAg}$ ) is reported in Africa (8.8\%) and Western Pacific (5.3\%) (1). The prevalence of chronic HBV ranges from $2 \%$ to $8 \%$ in Turkey and is located in intermediate- prevalence areas (2). It is estimated that HBV carriers in Turkey is 3.3 million and the overall HBsAg prevalence is $4.5 \%$ (3). The transmission of HBV can occur through various body fluids such as infected blood and blood products, from mother to baby, sexual contact with the unvaccinated individual, acupuncture, tattoo and/or saliva, vaginal secretions as well as seminal fluids (4). Today, it is tried to lower the risk of developing liver failure, cirrhosis and subsequent cancer with the follow-up and treatment of HBV infections (5).

Laboratory diagnosis of HBV infection can be performed by using different serological and molecular techniques as well as liver biopsy which plays an important role in treatment in patients with chronic hepatitis $(\mathrm{CH})$ (6). Although liver biopsy is still considered as the gold standard for the determination of liver fibrosis and necro-inflammatory activity, laboratory methods are preferred because of temporary pain in the biopsy site, mild transient hypotension, as well as more serious complications such as bleeding, biliary peritonitis, bacteremia, sepsis, pneumothorax and rarely death (7). HBV infections can be identified by routine applications of serological and molecular markers (8). On the other hand, serum HBV-DNA levels that can be used in the treatment of chronic hepatitis $\mathrm{B}(\mathrm{CHB})$ can be measured by hybridization and polymerase chain reaction (PCR) based molecular techniques (9). Real-time PCR (rt-PCR) based molecular quantitation techniques such as Qiagen, Abbott, COBAS Ampliprep platforms are routinely used in our country (9). In order to determine viral load of HBV quantitatively, rt-PCR kits are also designed in our country.

In this study, we aimed to compare Qiagen HBV-DNA quantitative kit and lontek HBV-DNA quantitative kit produced in our country by using sera of patients with chronic HBV infected with genotype $\mathrm{D}$.

\section{Materials and Methods}

In this retrospective study, a total of $87 \mathrm{CHB}$ patients infected with HBV genotype $D$ were sent to the routine PCR unit of Kocaeli University Research and Application Hospital for HBVDNA quantitation. HBV-DNA loads were obtained by using rt-PCR technique with Qiagen (Artus Hilden HBV QS RGQAR Qiagen, Germany) and lontek (lontek Istanbul, Turkey) kits simultaneously, according to the manufacturer's instructions and all tests were repeated twice for both kits. The obtained viral loads in $\mathrm{U} / \mathrm{mL}$ were converted into log $\mathrm{IU} / \mathrm{mL}$ values that were used in the correlation analysis between Qiagen and lontek assays.

The study was approved by the Clinical Research Ethics Committee of Kocaeli University (approval number: KAEK 2011/104). Since our study was retrospective, informed consent was not used.

\section{Statistical Analysis}

For the comparison Qiagen and lontek HBV-DNA quantitation, HBV-DNA logarithmic (log) value distributions were determined and their mean and standard deviations (SD) were calculated. The statistical differences between HBV log values obtained from two kits, were calculated. The hypotheses constructed for the t-test used for this purpose were $\mathrm{HO}$ : the difference between the means was $\mathrm{O}$ and $\mathrm{Ha}$ : the difference between the means was different from 0 . The confidence intervals $(\mathrm{Cl})$ between the obtained measurements were determined and the measurements were examined for linearity. The hypotheses designed for this purpose; $\mathrm{HO}$; the relationship between the two variables is linear and $\mathrm{Ha}$; The relationship between the two variables was determined as non-linear.

Significance of the difference between HBV-DNA log values of both kits was defined by $p$ value $(>0.5)$ according to t-test. The $\mathrm{Cl}$ of the difference between the two measurements was calculated according to the Bland-Altman distribution. The linearity between the two measurements was determined by PassingBablok regression analysis.

For all statistical analyzes and figures, XLSTAT (Addinsoft Inc., New York, USA) statistical program was used.

\section{Results}

HBV-DNA loads were obtained by quantitative rt-PCR method in serum samples of $87 \mathrm{CHB}$ patients infected with HBV genotype D. HBV loads were defined as $1 \mathrm{U} / \mathrm{mL}$, but these values were converted to log values for all statistical analyzes. Log values obtained from the results of Qiagen and lontek kits were used in this study.

HBV-DNA log values obtained with the kits of both manufacturers were compatible with each other (bias within 95\% Cl: -0.84; SD: 0.67). According to the serum HBV-DNA log value distributions, the most frequent viral load was detected in the range of 2.50-3.39, while the low frequency HBV-DNA loads were found in the values of 9.08-9.26 log. While the viral load was detected in 2 samples with 0.73 log values with the lontek kit, no viral load of the same value was detected with the Qiagen kit. The distribution of frequency and log values of the patient samples is shown in Table 1. Qiagen and lontek HBV-DNA quantitation log distribution graph is demonstrated in Figure 1.

The mean \pm SD values for Qiagen and lontek kits were found as $3.7950 \pm 2.0579$ and $3.7127 \pm 1.9598$ respectively. According to t-test, $p$ value was found to be $0.0505>0.5$.

Bland - Altman plot shows statistical comparison between two measurements. The bias and the standard error were found as -0.0824 and 0.3873 . The $\mathrm{Cl}$ for the difference between the two measurements was found to be $(-0.8415 ; 0.6768)$. Bland-Altman distribution analysis is shown in Figure 2.

The Passing - Bablok test was used to determine the linearity between the two test results. In the Passing - Bablok regression analysis, p value was measured as 0.6190>0.5. Qiagen and lontek HBV-DNA log values were determined within 95\% Cl. Passing Bablok linearity analysis is given in Figure 3 . 


\begin{tabular}{|c|c|c|c|c|}
\hline \multirow[b]{2}{*}{ HBV-DNA loads (IU/mL) } & \multicolumn{2}{|l|}{ Qiagen } & \multicolumn{2}{|l|}{ Iontek } \\
\hline & Frequency, $n$ & Log-mean* & Frequency, n & Log-mean* \\
\hline $10^{1}-<10^{2}$ & 7 & 1.69 & 10 & 1.67 \\
\hline $10^{2}-<10^{3}$ & 32 & 2.50 & 24 & 2.54 \\
\hline $10^{4}-<10^{5}$ & 7 & 4.19 & 5 & 4.39 \\
\hline $10^{5}-<10^{6}$ & 5 & 5.67 & 6 & 5.61 \\
\hline $10^{6}-<10^{7}$ & 3 & 6.38 & 2 & 6.31 \\
\hline $10^{7}-<10^{8}$ & 3 & 7.89 & 4 & 7.48 \\
\hline
\end{tabular}

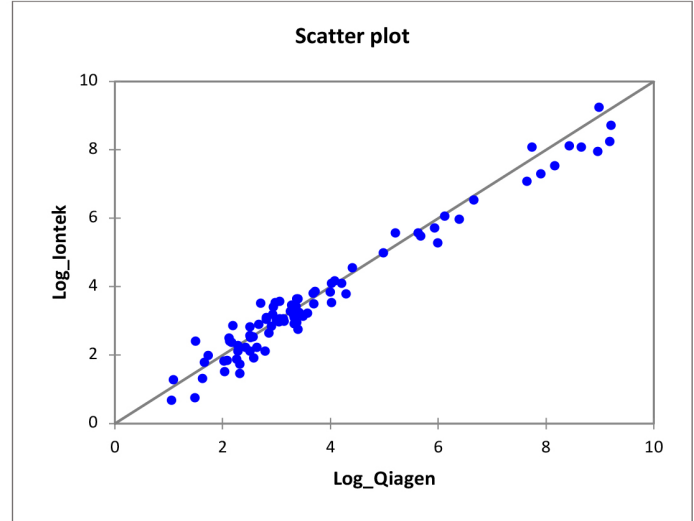

Figure 1. Qiagen and lontek hepatitis B Virus-DNA quantitation log distribution graph

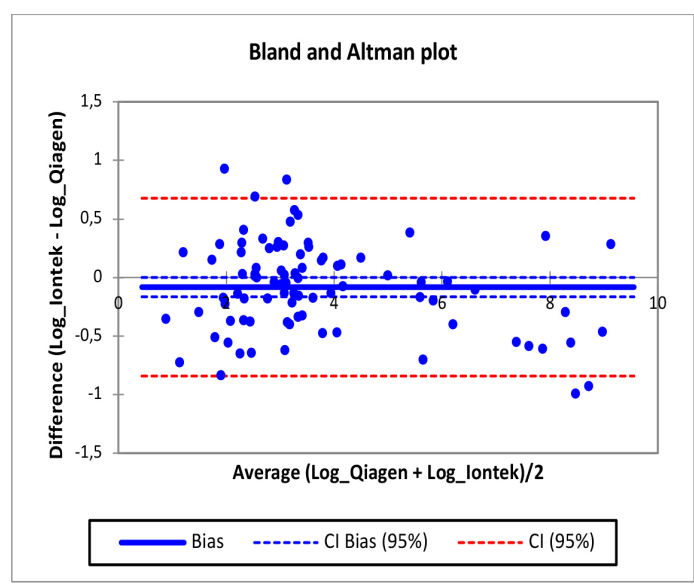

Figure 2. Bland Altman distribution. Statistical comparison of Qiagen and lontek hepatitis B Virus-DNA quantitation within 95\% confidence interval

$\mathrm{Cl}$ : Confidence interval

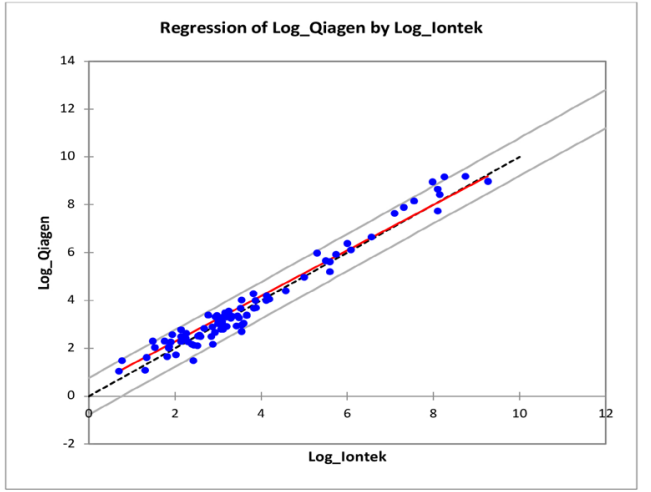

Figure 3. Passing - Bablok regression distribution. Linearity comparison in Qiagen and lontek hepatitis B Virus-DNA quantitation

\section{Discussion}

HBV-DNA viral load analyzes used to confirm HBV infection and to evaluate antiviral response are considered to be a good indicator of viral replication and are often expressed using different units such as copies $/ \mathrm{mL}$ or $\mathrm{IU} / \mathrm{mL}(5,10,11,12)$. On the other hand, the World Health Organization recommends that serum HBV-DNA concentration to be expressed as standard $\mathrm{IU} / \mathrm{mL}$ in monitoring the success of oral antiviral therapy in $\mathrm{CHB}$ patients (13). However, in order to express the performance characteristics of kits or methods as standard in comparative analyzes, viral load values are used by converting them to log values $(14,15,16)$. In this study that focused on comparing Qiagen and lontek HBV-DNA quantitation kits, HBV-DNA loads were defined in IU/mL, but these results were converted to log values for all statistical analyzes. In the HBV log value distribution graph, the correlation between the two variables was found to be consistent (Figure 1). There was no statistically significant difference between the results ( $p$ value: 0.0505). According to our findings, the hypothesis HO: (difference between the averages was 0) was accepted, whereas the $\mathrm{Ha}$ hypothesis (difference between the averages was different from 0) was rejected. 
The reliability and reproducibility of any test kit and/or method must be measured before routine use. Therefore, the difference between the values obtained should be expected to be acceptable (17). In this study, distribution analyzes were used to understand the agreement between the two kits. For this purpose, BlandAltman and Passing-Bablok analyzes were used. According to our findings, HBV-DNA log values obtained with Qiagen and lontek kits were statistically compatible in Bland-Altman distribution within 95\% $\mathrm{Cl}(-0.84$ and -0.67$)$. In addition, the HBV-DNA log values obtained with the Qiagen and lontek kits were linear according to the Passing Bablok distribution ( $p$ value; 0.6190). Bland Altman and Passing - Bablok distribution analyzes are the methods used to investigate the harmony between different methods or variables which are accepted as the gold standard in the statistical analysis of the comparison studies (18).

It is aimed to improve quality of life of people with $\mathrm{CHB}$ with lifelong follow-up and treatment. Often oral antivirals and rarely immunoregulatory agents (peg - interferon) are used in the treatment of $\mathrm{CHB}$ for this purpose $(5,19)$. Oral antiviral therapy is based on lifelong HBV suppression and reduction of liver inflammation. However, serum HBV-DNA levels should be checked at regular intervals and treatment response should be monitored in patients with $\mathrm{CHB}$ during treatment (5). Many commercial kits are currently used to measure viral load by rt-PCR based technique (9). It will be beneficial for our country to produce analysis kits that can be used in molecular diagnosis. In many studies, Qiagen kits were compared with different platforms such as Roche, Abbott, DxN VERIS in terms of business model or performance characteristics $(9,12,20)$. However, our knowledge about the performance characteristics of CE marked lontek HBV-DNA quantitation kit that is produced in our country is limited. Our findings indicate that results of lontek HBV-DNA rt-PCR kit are compatible with Qiagen rt-PCR kit results HBV-DNA in serum samples of patients with chronic HBV infected with HBV genotype D.

\section{Conclusion}

In conclusion, comparative distribution analysis of Qiagen and Iontek HBV-DNA viral load kits shows us that a product from our country can be used safely in the treatment follow-up of $\mathrm{CHB}$ patients. Such studies may be useful in supporting the production of high value-added products in our country while being delivered to other users in the world.

\section{Ethics}

Ethics Committee Approval: The study was approved by the Clinical Research Ethics Committee of Kocaeli University (approval number: KAEK 2011/104).

Informed Consent: Since our study was retrospective, informed consent was not used.

Peer-review: Externally and internally peer-reviewed.

\section{Authorship Contributions}

Surgical and Medical Practices: M.S., Concept: A.A., M.S., Design: A.A., M.S., Data Collection or Processing: M.S., Analysis or Interpretation: A.A., M.S., Literature Search: A.A., M.S., Writing: A.A., M.S.
Conflict of Interest: The authors declare no conflict of interest.

Financial Disclosure: The authors declare that this study has not received any financial support.

\section{References}

1. Kim BY, Kim WY. Epidemiology of hepatitis B virus infection in the United States. Clinical Liver Disease. 2018;12:1-4.

2. Asan A, Sayan M, Akhan S, Koruk ST, Aygen B, Sirmatel F, Eraksoy $H$, Tuna N, Köse S, Kaya A, Tulek NE, Demir NA, Mistik R, Ormen B, Korkmaz F, Yildirmak T, Ural O, Aydin M, Turgut H, Gunal O, Demirturk N. Molecular characterization of drug resistance in hepatitis $B$ viruses isolated from patients with chronical infection in Turkey. Hepat Mon. 2018;18:e12472.

3. Aytac O, Toyran A, Aksoy A. Importance of HBsAg neutralization test in the diagnostic algorithm of hepatitis $B$ disease. Mikrobiol Bul. 2017:51:136-144.

4. 4.World Health Organization (WHO), 2018 Key Facts Sheet [updated 2018 July] Available from: https://www.who.int/en/newsroom/fact-sheets/detail/hepatitis-b.

5. Ward H, Tang L, Poonia B, Kottilil S. Treatment of hepatitis B virus: an update. Future Microbiol. 2016;1:1581-1597.

6. Afyon M, Artuk C. Atypical serological profiles in hepatitis B virus infection. TAF Preventive Med Bulletin. 2016;15:267-276.

7. Kose S, Ersan G, Tatar B, Adar P, Sengel BE. Evaluation of percutaneous liver biopsy complications in patients with chronic viral hepatitis. Eurasian J Med. 2015;47:161-164.

8. Terrault NA, Lok ASF, McMahon BJ, Chang KM, Hwang JP, Jonas MM, Brown RS Jr., Bzowej NH, Wong JB.Update on prevention, diagnosis, and treatment and of chronic hepatitis B: AASLD 2018 Hepatitis B guidance. Hepatol. 2018;67:1560-1599.

9. Sayan M, Arıkan A, Şanlıdağ T. Comparison of performance characteristics of DxN Veris system versus giagen pcr for HBV genotype $\mathrm{D}$ and HCV genotype $1 \mathrm{~b}$ quantification. Polish $\mathrm{J}$ Microbiol. 2019;68:139-143.

10. Kawanaka M, Nishino K, Nakamura J, Oka T, Urata N, Goto D et al. Quantitative levels of hepatitis B virus DNA and surface antigen and the risk of hepatocellular carcinoma in patients with hepatitis $B$ receiving long-term nucleos(t)ide analogue treatment. Liver Cancer. 2014;3:41-52

11. Arıkan A, Sanlıdağ T, Süer K, Sayan M, Akçalı S, Güler E. Molecular epidemiology of hepatitis B virus in Northern Cyprus. Mikrobiol Bul. 2016:50:86-93.

12. Han MS, Park Y, Nah H, Kim HS. Comparison of the QIAGEN artus HBV QS-RGQ Assay with the Roche COBAS AmpliPrep/COBAS TaqMan HBV assay for quantifying viral DNA in sera of chronic hepatitis B patients. Ann Lab Med. 2017;37:248-253.

13. Frer JF, Minhas R, Dougall T, Rigsby P, Morris CL. Collaborative study to evaluate the proposed WHO 4th international standard for hepatitis B virus (HBV) DNA for nucleic acid amplification technique (NAT) based assays. Expert Committee on Biological Standardization, World Health Organization 2016. https://www. who.int/biologicals/ECBS_2016_BS2291_HBV_4th_IS_WHO_BS_ Report_Final.pdf

14. Oiu N, Li R, Yu JG, Yang W, Zhang W, An Y. Comparison of Abbott and da-a real time PCR for quantitating serum HBV DNA. World $\mathrm{J}$ Gastroenterol. 2014;30:11762-11769.

15. Li M, Chen L, Liu L, Li YL, Li BA, Li B. Performance verification and comparison of tian long automatic hypersensitive hepatitis $B$ virus DNA quantification system with Roch CAP/CTM system. World J Gastroenterol. 2017;23:6845-6853.

16. Li WJ, Xu HX, Wu DS, Wu YJ, Xu WD. A novel fully automated system for quantification of hepatitis $B$ virus DNA using magnetic 
bead-based method combined with real time PCR. J Virol Methods. 2017;248:130-135.

17. Sarclı S, Celik H.E. Comparison of bland-a and type II regression analysis in method comparison studies. Duzce University Journal of Institute of Health Sciences. 2013;2:11-14.

18. Mayer B, Gaus W, Braisch U. The fallacy of passing-bablok regression. Jokull Journal. 2016;66:95-106.
19. Kirdar S, Yasa M.H, Sayan M, Aydın N. HBV pol/S gene mutations in chronic hepatitis B patients receiving nucleoside / nucleotide analogue treatment. Mikrobiol Bul. 2019;53:144-155.

20. Braun $P$, Delgado $R$, Drago $M$, Fanti D, Fleury $H$, Izopet J. A European multicenter study on the comparison of HBV viral loads between Veris HBV assay and Roch Cobas, Taqman HBV test, Abbott real time PCR HBV assay, Siemens versant HBV assay and Qiagen Artus HBV RO kit. J Clin Virol. 2017;95:76-83. 